\title{
THE NUMBER OF LARVAL STAGES IN THE GENUS NADATA.
}

\author{
BY HARRISON G. DYAR, BOSTON, MASS.
}

In Psyche, recently, I expressed the opinion that species of Nadata had more than six larval stages, which was founded on certain measurements made from Nadata gibbosa. I have not since obtained this species in the early st:ages.* but have bred another from the egg, which is $N$. oregonensis Butl. In this species, the number of stages appears to be normally six ; but two individuals,

\footnotetext{
* Miss Soule has recently written the life history of N. gibbosa (Psyche, v. 6, 197) and found tive stages, as did also Dr. Riley (See $5^{\text {th }}$ rept. U. S. ent. coin., 1890). Unfortunately, Miss Soule has given no measurements of the head, but she has given the length of the larva in all its stages and the numbers she gives correspond well with a series derived with the ratio .60. This does no: corroborate my observations (on $N$. oregonensis), as, to do so, a stage should appear lacking between stages I and II, provided that the measurements were made at the first of each stage. Miss Soule's figures are $3.16(=.19), \frac{1}{4}(=.25), \frac{1}{2}(=.50), \frac{3}{4}(=.75)$, and $1 \frac{1}{4}(=1.25)$ inches while the calculated series would be $. \mathrm{r} 6, .27, .45, .75, \mathrm{r} .25$ in., thus showing no gap in the series anywhere. To suit my observations the newly hatched larva should have measured .ro inch instead of .16 inch. Miss Soule says "not quite 3 -16 in.," which is certainly nearer .16 than .10, as the latter would be not quite $\frac{1}{8}$ in.

But I do not think the length of the larva is a reliable measurement to take as it is subject to great change throughout the stage, and, even if taken as nearly as possible at the same time in each stage, is subject to inaccuracies through the expansion or contraction of the larval segments. Moreover it takes no account of the growth during either the first or the last stage, according as the measurements are made at the end or beginning of each stage, and I shou!d hesitate to assume that the growth was always strictly proportional. In fact, I believe that in Nadata it is not so, for double growth seems to take place in the first stage.

The measurement of the width of head is open to none of the above objections and possesses besides sev. eral advantages not shown by measurements of the length of the larva.
}

carefully bred in confinement and two bred in the open air had but five stages, while another specimen, less carefully reared in confinement beside another bred in the open air on its growing food plant under a net exhibited six stages, but not the normal ones. All the larvae appeared to omit the normal second stage, even those that had six stages. These latter inserted an extra stage between the fourth and fifth, not differing in markings from the fourth, as will be seen in what follows. The growth during the first stage was very great, out of all proportion to the subsequent growth, and, previous to moulting, the new head in process of formation behind the old one, caused an enormous projection of the body.

The calculated normal series for the widths of head stands as follows :-I .79, [II I.13,] III ז.62, IV 2.3I, V 3.3, VI $4.7 \mathrm{~mm}$.; ratio .70 .

From the larvae that had five stages, I obtained the following measure-

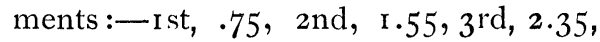
$4^{\text {th }}, 3.3,5^{\text {th }}, 4.7^{\mathrm{mm}}$.

From those that had six stages: first example: - Ist, ,* 2nd, I.4, $3^{\text {rd, }}$ $2.2,4^{\text {th }}, 2.7,5^{\text {th }}, 3.2,6$ th, $\mathrm{mm}$. : $\dagger$ second example:-ist, , * 2nd, r.5, $3^{\mathrm{rd}}, 2.3,4^{\text {th }}, 2.8$, $5^{\text {th }}, 3.7$, 6th, 4.8 $\mathrm{mm}$.

\footnotetext{
* Measurement not recorded.

t This larva died before moulting the last time.
} 
It will be seen that in the first example an extra stage occurred between the normal stages IV and $\mathrm{V}$, and this is verified by the changes in markings; for in those that had five stages, the markings changed in the fourth stage, while in this, the fourth stage was like the third and the change did not occur till the fifth stage.*

In the second example the fifth stage was abnormally large, so much so that the last four stages, in this case, present a good series with the ratio .77 . and, judging from these stages only, it would certainly be inferred that the species had eight larval stages, $\dagger$ with the following series of widths of head:calculated-.77, 1.0, I.3, I.7, 2.2, 2.8, $3 \cdot 7,4.8$, mm., ratio .77 . Compare with this the last four measurements of the second example.

The species of Nadata, then, present examples of variation in the number of larval stages, as well as an abnormal development.

It is probable that Edema albicosta acts in a similar, though less pro-

\footnotetext{
* In this connection I would like to call attention to my note on Spilosoma latipennis (Ent. news, v. 2, p. I15) where it will be seen an extra stage occurred between normal stages VIII and IX, not differing in markings from the stage before it, exactly as in the present instance. These cases are not analogous with such as are exhibited in Orgyia where an extra stage occurs in $q$ larvae, for the latter takes place to afford an increase in size. In the present instances the larvae with the extra stage are no larger than those with the normal number, and the stage is interpolated betore the final stage instead of occurring after it.

t From similar measurements made in the case of $N$. gibbosa, I inferred that that species had more than six stages (see Psyche, v. 6, p. 147), but this inference is not justified by the facts. It will be found, however, to have occasionally as many as six stages.
}

nounced manner. $\ddagger$

The following descriptions apply to the species of Nadata that is common in the Yosemite Valley, Cal.

Nadata oregonensis Butler.§

I8S I-Butler, Ann. and mag. nat. hist., p. 3 I 7 .

behrensii Hy. Edwards.
I $885-\mathrm{Hy}$. Edw., Ent. Amer., i, 49.

Egg. Rather more than hemispherical, the base flattened; smooth, not shiny, white with a yellowish tinge; diameter $1.2 \mathrm{~mm}$. Under a microscope the surface is seen to be covered with very slight, obscure, rounded depressions, but, in fact, almost smooth.

Laid singly on the under side of the leaves of its food plants in early summer.

$\ddagger$ The series of widths of head as observed by me for Edema albicosta were .40, .7०, 1.30, 1.7, 2.3, 3.2, and I have twice attempted in the pages of Psyche to make them fit a series in regular geometrical progression, but without marked success. A series calculated with the ratio .55 would give- $.41, .75,1.27,2.30,4.3$, and one with the ratio .73 or thereabout would interpolate a term between each one and give $.41, .55, .75, .96,1.27$, I.7, 2.3, 3.15, 4.3. Thus it might be considered either that the species normally had eight stages (ratio .73) and omitted the second and fourth normal stages, or that it had normally five stages (ratio .55), but interpolated a stage between the third and fourth normal stages, and reduced the measurement in the last stage to correspond with the ratio between those that immediately preceded it. The latter seems the more probable, but the fact is that the growth of the head at the first and second moults is double what it is at the third, fourth and fifth. It is a curious case.

$\S$ This was described as a variety of $N$. doubleday Pack.; but Mr. Butler writes me under date of June 30 , 1892-"The types . . . have pale creamy buff-colored palpi; quite uniform in tint ... if there is a brown line above it must be on the second joint, but I do not think there is one . . looking at the moth without a lens you would say the fringe was dark ferruginous on primaries ... and white tipped on interspaces." These are the characters used to separate $N$. gibbosa from $D$. doubledayi in Dr. Packard's description, and Mr. Butler's words show that his form is not a variety of $N$. doubledayi, but the same as $\mathrm{Hy}$. Edward's N. behrensii. 
Normal stage $I$. (First larval stage.) Head slightly bilobed, rounded, shining pale greenish with a few hairs; mouth brownish, ocelli black; width $0.75 \mathrm{~mm}$. Body slender, no tubercles or humps, feet normal; smooth, shiny, pale yellowish green. Setae minute, rather long but not evident, color blackish. As the stage advances, great growth takes place, the color becomes green with a yellow subdorsal line much as in the mature larva. The body is transversely creased. Duration of this stage about four days.

Normal stage $I I$. Not exhibited in any specimen seen by me and probably does not occur.

Normal stage III. (Second stage.) Head large, slightly bilobed, narrowing a little to vertex and flattened in front; pale green, hardly shiny; mouth white, ocelli and tips of jaws black; width I.4-I.55 mm. Body slender, smooth, no perceptible hairs; legs normal ; green, somewhat shiny, a broad yellowish green subdorsal line; spiracles black.

Normal stage IV. (Third stage.) Head as before; width $2.0-2.35 \mathrm{~mm}$. Body slender, uniform green; a very distinct, rather broad, pale yellow, subdorsal band from joint 2 to the anal plate; spiracles black, faintly surrounded by yellowish. Scattered, very small and short setae.

Normal stage IV. (Fourth stage in some larvae.) Head large, flattened in front, very slightly bilobed, smooth, not shiny, pale green; ocelli black, labrum white, jaws black at tips, otherwise green; width $2.7-2.8 \mathrm{~mm}$. Body transversely creased, leaf green with yellow piliferous dots bearing very small setae. A slightly darker dorsal line and broad yellow subdorsal line from joint 2 to the end of the anal plate. Spiracles black with small white centers.

Normal stage $V$. (Fourth or fifth stage.) Head shaped as before, pale green, not shiny, ocelli black on a white ground, labrum white at tip, jaws green tipped with black, antennae yellowish; width $3.2-3.7 \mathrm{~mm}$. Body yellowish green with many yellow irregular ellip- tical granulations and a distinct broad yellow subdorsal line, continuous from joint 2 to joint 13 and bordering the anal plate. which is rounded. Joint 2 is narrowly edged with yellow in front. Spiracles dark brown, paler centrally. Feet green, without any yellow spots.

Normal stage VI. (Fifth or sixth stage.) Head full, rounded, slightly shiny, and absoletely shagreened; partly retracted under joint 2; uniform leaf green, ocelli black on a white ground, mouth parts whitish, jaws straw yellow, tipped with black; clypeus small, triangular; width $4.6-4.8 \mathrm{~mm}$. Body cylindrical, full and rounded, tapering slightly to the last segment which is smaller. than the rest, leaf green or whitish green, densely covered with white, irregular, flattened elliptical granulations which on the venter become transverse streaks. In specimens in which the ground color is suffused with whitish, joint 2 , joint $\mathrm{I} 3$ posteriorly and the anal feet remain leaf green. A broad, distinct, white subdorsal line, faint on the anterior part of joint 2. The anterior edge of joint 2 and the border of the anal plate, are bright yellow. Feet green, the abdominal ones covered with white granulations, and a white line before claspers. Spiracles orange red, faintly bordered with white. The edges of the white subdorsal band are not even but more or less incised, on the anterior segments being narrowly broken into contiguous elliptical areas, or in some specimens broken throughout the whole length.

Cocoon. The larvae enter the ground to pupate and form a rough cocoon of a few strong silken threads.

Pupa. Cylindrical, tapering, rather thick posteriorly to the thorax, the ends rounded, most so anteriorly; movable sutures of abdomen deep; cremaster long, rather thick, tapering and ending in two short divergent points. Body shiny, densely punctured; cases creased and also shiny. Color black with a shade of brown on the abdomen. Length $22 \mathrm{~mm}$.; width $7 \mathrm{~mm}$. 
Food plant. Black oak (2uercus kelloggii Newberry).

Nadata oregonensis is not well distinguished from $N$. gibbosa Sm. \& Abb., especially in the larval state. It seems to be related to gibbosa much as Papilio rutulus is related to $P$. turnus among the butterflies. Its habitat is very probably coextensive with that of its food plant, which is said to be "on the coast ranges and on the western slope of the Sierra Nevada throughout California and as far north as the middle of Oregon; on mountain sides and summits only, or in the elevited valleys, not on the plains or near the sea."* Mr. Edwards recorded it from Siskiyou and Butte Counties and I found it in Mariposa County, and at Portland, Oregon but I am not aware that any record of its capture in the coast ranges has yet been made. $\dagger$

\title{
NOTES ON THE NESTING HABITS OF CERTAIN BEES.
}

\author{
BY A. S. PACKARD, PROVIDENCE, R. I.
}

These notes were made in 1865 to 1867 , and were used in writing the chapters in "Our Common Insects" entitled "The Home of the Bees," and were also in part utilized in my Guide to the Study of Insects, but the matter here offered for publication has been unpublished and is perhaps worthy of record.

Osmia simillima Smith, - A number of cells of this species were found in a deserted oak-gall of Diplolepis confuentus, individuals of both sexes appearing in the house Dec. 14,1865 , while one appeared during the second week of the following April, and lived a week in the breeding box. The earthen cells, eleven in number, were arranged irregularly so as to fit the concave vault of the gall, which was about two inches in diameter. The cells are rudely cylindrical, a third longer than broad, and quite different in appearance from the cells of Odynerus, which are also built in these empty galls. The cells within are shining mahogany-colored, but externally are rough with the debris of the interior of the deserted gall. They differ from the cells of Odynerus in being parchment-like, while those of the latter are made of mud thinly lined within with white silk, and those of Osmia are a fourth larger. The insect cuts a longitudinal ovate lid, nearly as large as one side of the cell itself, which is attached to the posterior end by a hinge. Odynerus makes its exit by a hole at the end of its cell.

OsmIA PACIFICA Say. - Individuals of both sexes were found in the perfect state in cocoons and earthen cells beneath stones April 15. The cell is half an inch in length; breadth .28 inch. It is oval cylindrical, a little contracted at the upper end just before the lid, forming an urn-shaped oblique lid, which is flattened and a little depressed at the middle. The cell is thin and composed of black fine earth, and not lined with silk within; the outer surface is not very rough.

Megachile centuncularis. - The cells or cocoons of what is probably this species are cylindrical, very obtuse at each end, the walls of tough, parchment-like consistency,

* E. L. Greene, Illus. of West Amer. oaks, page 2, 1889.

t I have recently seen examples of the species in the collection of Prof. Rivers from Napa Co., Cal. and it has been taken at Seattle, Wash., by Johnson. 

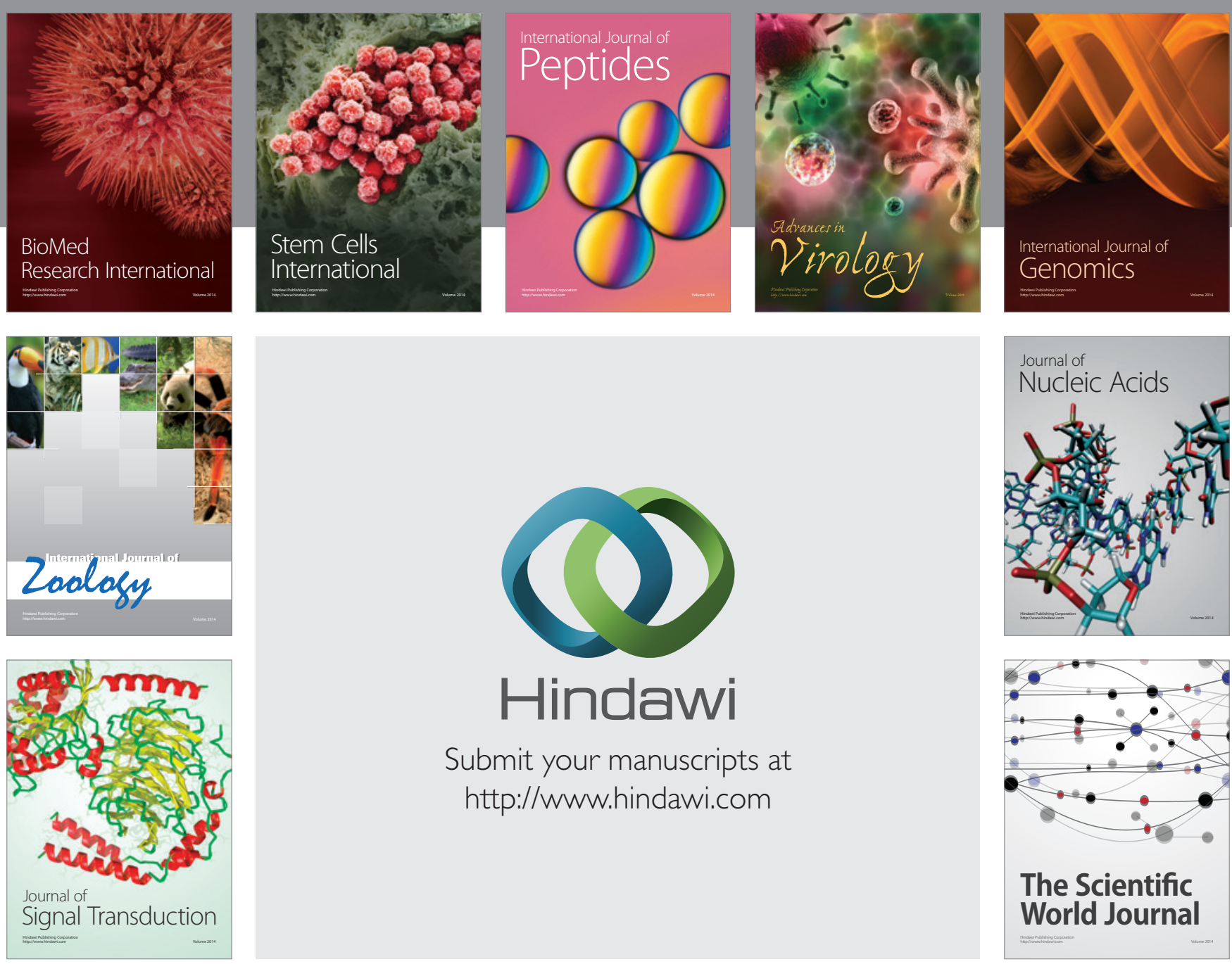

Submit your manuscripts at

http://www.hindawi.com
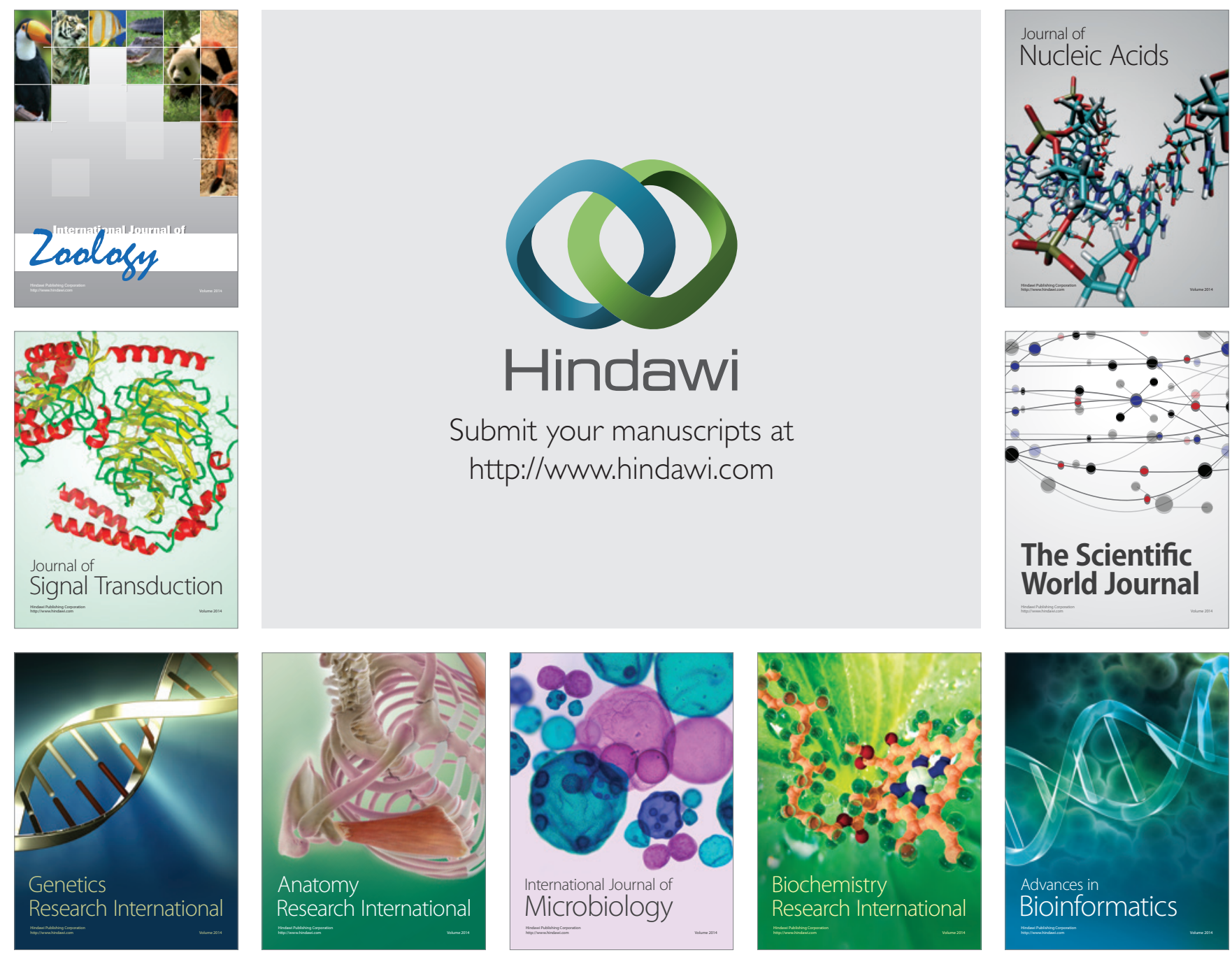

The Scientific World Journal
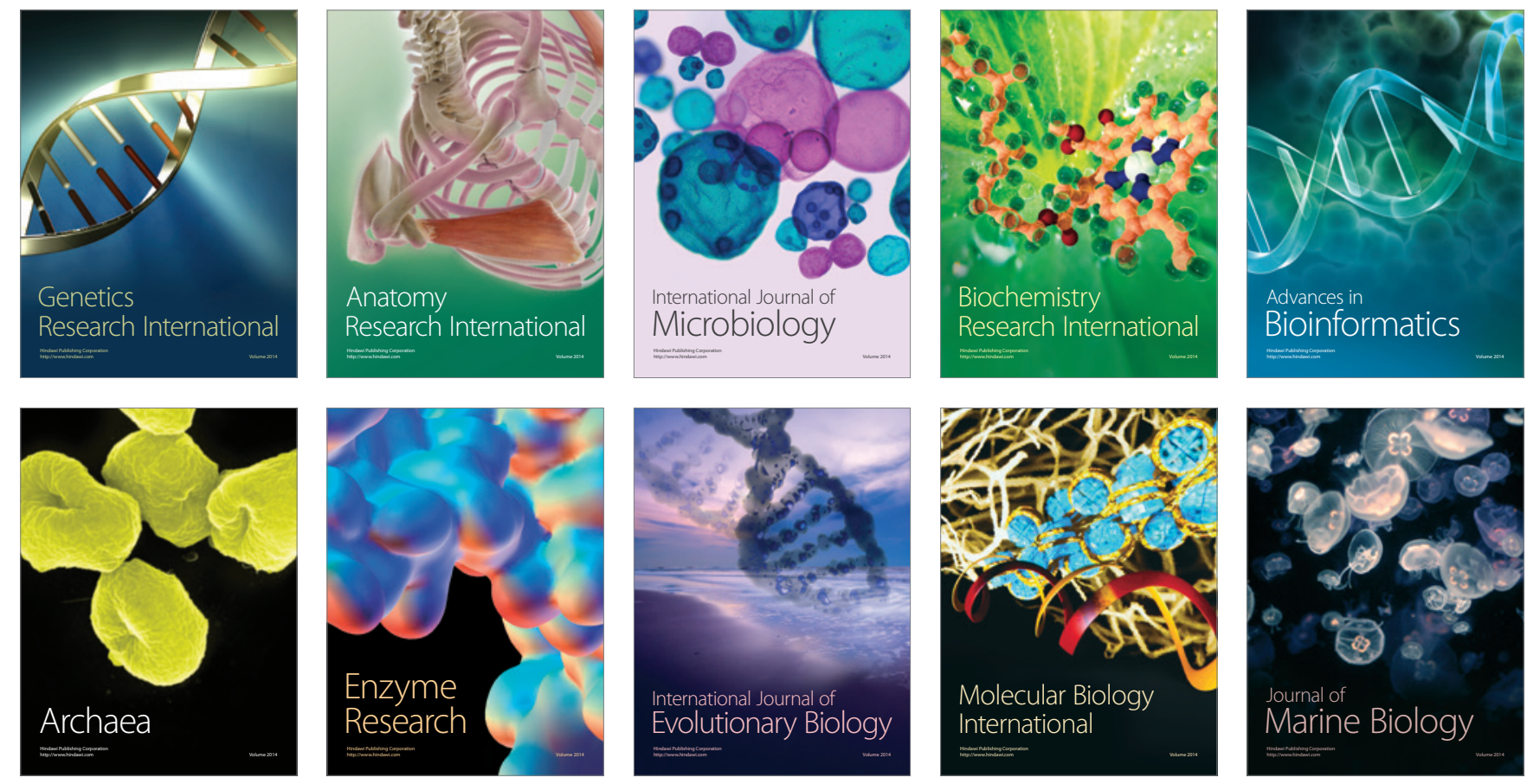